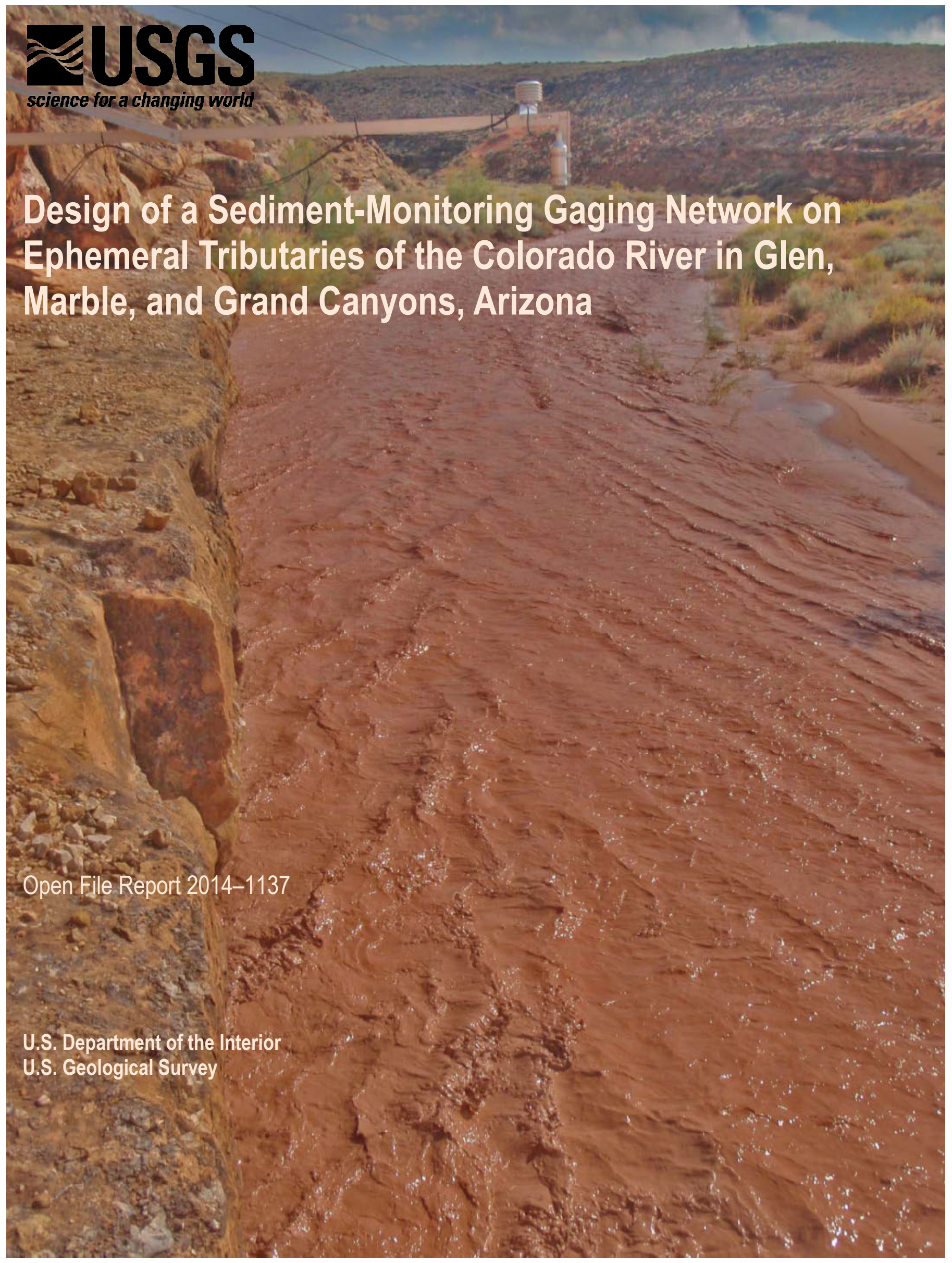


COVER: House Rock Wash above Emmett Wash gaging station looking downstream. Photography by Ronald Griffiths, 2010 


\section{Design of a Sediment-Monitoring Gaging Network on Ephemeral Tributaries of the Colorado River in Glen, Marble, and Grand Canyons, Arizona}

By Ronald E. Griffiths, David J. Topping, Robert S. Anderson, Gregory S. Hancock, and Theodore S. Melis

Open File Report 2014-1137

U.S. Department of the Interior

U.S. Geological Survey 


\section{U.S. Department of the Interior \\ Sally Jewell, Secretary}

\section{U.S. Geological Survey \\ Suzette Kimball, Acting Director}

U.S. Geological Survey, Reston, Virginia 2014

For more information on the USGS-the Federal source for science about the Earth, its natural and living resources, natural hazards, and the environment-visit http://www.usgs.gov or call 1-888-ASK-USGS

For an overview of USGS information products, including maps, imagery, and publications, visit http://www.usgs.gov/pubprod

To order this and other USGS information products, visit http://store.usgs.gov

Suggested citation:

Griffiths, R.E., Topping, D.J., Anderson, R.S., Hancock, G.S., and Melis, T.S., 2014, Design of a sedimentmonitoring gaging network on ephemeral tributaries of the Colorado River in Glen, Marble, and Grand Canyons, Arizona: U.S. Geological Survey Open File Report 2014-1137, 21 p., http://dx.doi.org/10.3133/ofr20141137.

ISSN 2331-1258 (online)

Any use of trade, firm, or product names is for descriptive purposes only and does not imply endorsement by the U.S. Government.

Although this information product, for the most part, is in the public domain, it also may contain copyrighted materials as noted in the text. Permission to reproduce copyrighted items must be secured from the copyright owner. 


\section{Contents}

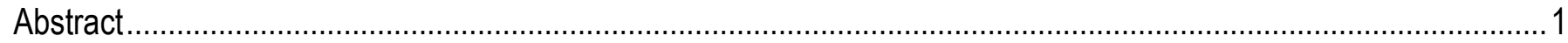

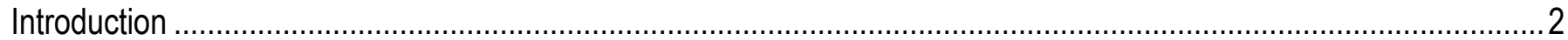

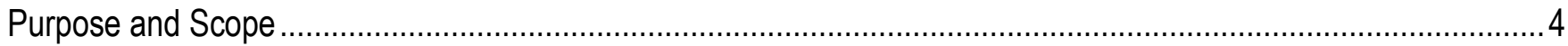

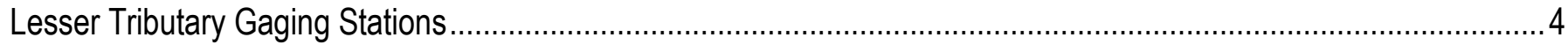

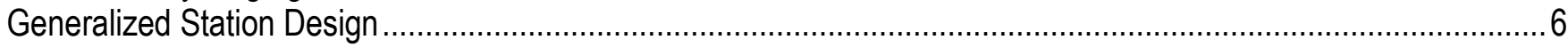

Station Placement Considerations.

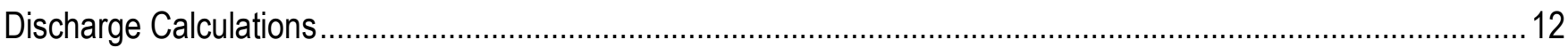

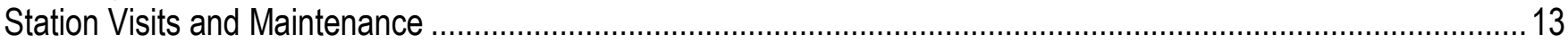

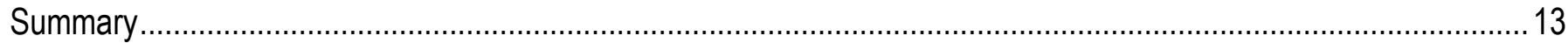

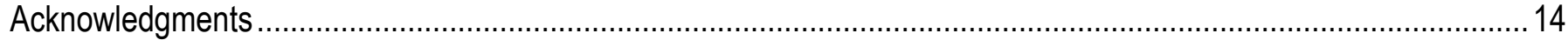

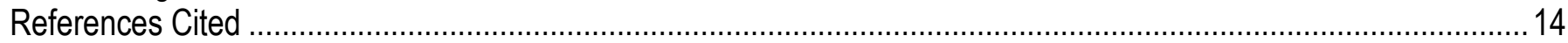

Appendix: Campbell Scientific CR10X, SR50, and Onset Rain Gage .............................................................. 16

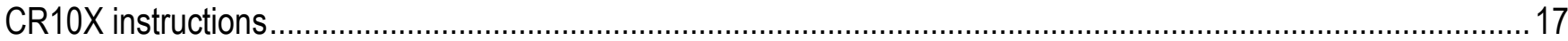

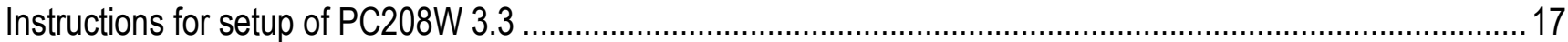

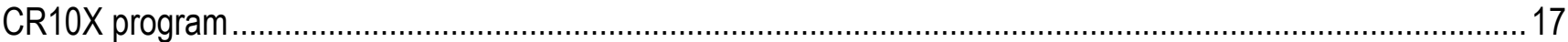

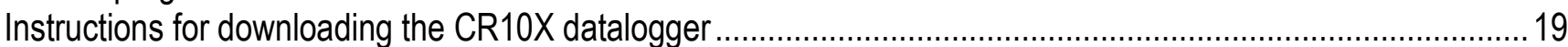

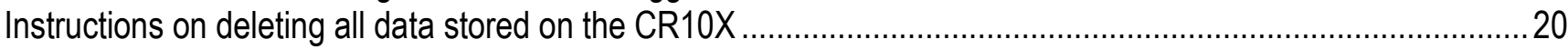

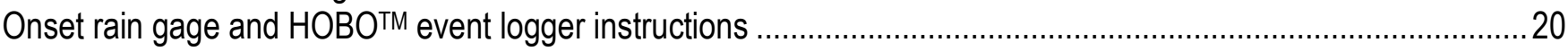

\section{Figures}

1. Digital elevation map showing the lesser tributary stage and suspended-sediment gaging stations........5

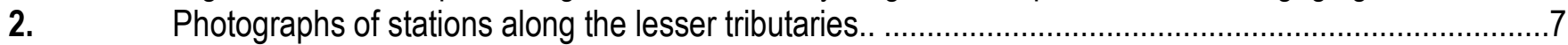

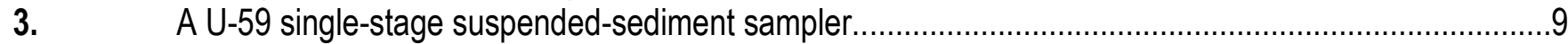

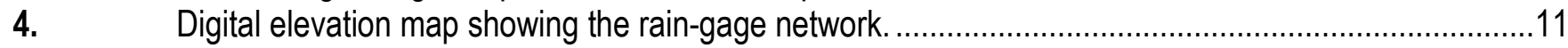

\section{Tables}

1. Equipment present at each sediment-monitoring gaging station. 
Conversion Factors

\begin{tabular}{lll}
\hline \multicolumn{1}{c}{ Multiply } & \multicolumn{1}{c}{ By } & \multicolumn{1}{c}{ To obtain } \\
\hline centimeter $(\mathrm{cm})$ & 0.3937 & inch (in) \\
millimeter $(\mathrm{mm})$ & 0.03937 & inch (in) \\
micron $(\mu)$ & 0.00003937 & inch (in) \\
meter $(\mathrm{m})$ & 3.281 & foot $(\mathrm{ft})$ \\
kilometer $(\mathrm{km})$ & 0.6214 & mile (mi) \\
liter $(\mathrm{L})$ & 0.2642 & gallon $(\mathrm{gal})$ \\
cubic meter per second $\left(\mathrm{m}^{3} / \mathrm{s}\right)$ & 35.31 & cubic foot per second $\left(\mathrm{ft}^{3} / \mathrm{s}\right)$ \\
\hline
\end{tabular}

Horizontal coordinate information is referenced to the North American Datum of 1983 (NAD 83).

\section{Abbreviations}

ABS

GCMRC

GCNP

MMT

NPS

Reclamation

USGS acrylonitrile butadiene styrene

Grand Canyon Monitoring and Research Center

Grand Canyon National Park

Million metric tons

National Park Service

U.S. Department of the Interior, Bureau of Reclamation

U.S. Geological Survey 


\title{
Design of a Sediment-Monitoring Gaging Network on Ephemeral Tributaries of the Colorado River in Glen, Marble, and Grand Canyons, Arizona
}

\author{
By Ronald E. Griffiths, David J. Topping, Robert S. Anderson, Gregory S. Hancock, and Theodore S. Melis
}

\begin{abstract}
Management of sediment in rivers downstream from dams requires knowledge of both the sediment supply and downstream sediment transport. In some dam-regulated rivers, the amount of sediment supplied by easily measured major tributaries may overwhelm the amount of sediment supplied by the more difficult to measure lesser tributaries. In this first class of rivers, managers need only know the amount of sediment supplied by these major tributaries. However, in other regulated rivers, the cumulative amount of sediment supplied by the lesser tributaries may approach the total supplied by the major tributaries. The Colorado River downstream from Glen Canyon has been hypothesized to be one such river. If this is correct, then management of sediment in the Colorado River in the part of Glen Canyon National Recreation Area downstream from the dam and in Grand Canyon National Park may require knowledge of the sediment supply from all tributaries. Although two major tributaries, the Paria and Little Colorado Rivers, are well documented as the largest two suppliers of sediment to the Colorado River downstream from Glen Canyon Dam, the contributions of sediment supplied by the ephemeral lesser tributaries of the Colorado River in the lowermost Glen Canyon, and Marble and Grand Canyons are much less constrained. Previous studies have estimated amounts of sediment supplied by these tributaries ranging from very little to almost as much as the amount supplied by the Paria River. Because none of these previous studies relied on direct measurement of sediment transport in any of the ephemeral tributaries in Glen, Marble, or Grand Canyons, there may be significant errors in the magnitudes of sediment supplies estimated during these studies. To reduce the uncertainty in the sediment supply by better constraining the sediment yield of the ephemeral lesser tributaries, the U.S. Geological Survey Grand Canyon Monitoring and Research Center established eight sediment-monitoring gaging stations beginning in 2000 on the larger of the previously ungaged tributaries of the Colorado River downstream from Glen Canyon Dam. The sediment-monitoring gaging stations consist of a downward-looking stage sensor and passive suspended-sediment samplers. Two stations are equipped with automatic pump samplers to collect suspended-sediment samples during flood events.

Directly measuring discharge and collecting suspended-sediment samples in these remote ephemeral streams during significant sediment-transporting events is nearly impossible; most significant run-off events are short-duration events (lasting minutes to hours) associated with summer thunderstorms. As the remote locations and short duration of these floods make it prohibitively expensive, if not impossible, to directly measure the discharge of water or collect traditional depthintegrated suspended-sediment samples, a method of calculating sediment loads was developed that includes documentation of stream stages by field instrumentation, modeling of discharges associated with these stages, and automatic suspended-sediment measurements. The approach developed is as follows (1) survey and model flood high-water marks using a two-dimensional hydrodynamic model, (2)
\end{abstract}


create a stage-discharge relation for each site by combining the modeled flood flows with the measured stage record, (3) calculate the discharge record for each site using the stage-discharge relation and the measured stage record, and (4) calculate the instantaneous and cumulative sediment loads using the discharge record and suspended-sediment concentrations measured from samples collected with passive US U-59 samplers and ISCO ${ }^{\mathrm{TM}}$ pump samplers. This paper presents the design of the gaging network and briefly describes the methods used to calculate discharge and sediment loads. The design and methods herein can easily be used at other remote locations where discharge and sediment loads are required.

\section{Introduction}

In arid and semi-arid environments, short-duration, high-intensity rainfall events are the primary driver of sediment transport in ephemeral streams (for example, Wolman and Miller, 1960; Graf, 1983; Sharma and Murthy, 1994; Coppus and Imeson, 2002). The spatial and temporal variability of these rainfall events results in episodic and irregular stream flow and resultant sediment transport. For longterm geomorphic studies, the episodic nature of the sediment-transporting events may be irrelevant, but for shorter duration studies, especially sediment mass balance studies, knowing the actual short-term sediment yield, as opposed to the average sediment yield, is essential. Whereas sediment yield data may be important, measuring discharge and collecting suspended-sediment samples on ephemeral streams in arid regions is difficult and time-consuming. Limited-flow durations require that field technicians closely monitor weather conditions to promptly respond to possible flow events. Because of these limitations, few sediment-monitoring programs on ephemeral streams have been developed. Examples of sediment-monitoring gages and gaging networks constructed on arid ephemeral streams include Walnut Gulch, United States (Graf, 1983), Nahal Yael, Israel (Schick and Lekach, 1996; Schick, 2000), and the Luni River Basin, India (Sharma and others, 1984; Sharma and Murthy, 1994).

The difficulty in making measurements of discharge and suspended-sediment concentration on arid ephemeral streams has led many researchers to use methods such as regional sediment-yield equations (Webb and others, 2000), sediment-rating curves (Sutherland and Bryan, 1990), and peak discharge to total-sediment load relations (Rankl, 2002). These methods can provide a cost-effective estimation of sediment yield from ungaged tributaries. However, these approaches are limited by, among other factors, time averaging, hysteresis, and differences in local and regional geology, rainfall, and vegetation. For small drainage basins, monthly sediment loads have been found to vary up to two orders of magnitude from those predicted by sediment rating curves (Walling, 1977). Because of the limitations of indirect methods for calculating sediment yield discussed above, methods to measure discharge and sediment concentrations must be employed for streams where real-time sediment loads, rather than averaged sediment loads, are needed.

The Colorado River in Grand Canyon National Park (GCNP) experienced a dramatic reduction in the quantity of fine sediment (sand, silt, and clay) entering the river reach after completion of the Glen Canyon Dam; this reduction in sediment supply resulted in a net export of fine sediment (Schmidt and others, 2004). Currently, as a part of the U.S. Department of the Interior's Glen Canyon Dam Adaptive Management Program (Campbell and others, 2010), near real-time suspended-sediment monitoring occurs at multiple locations on the Colorado River (Topping and others, 2004; Griffiths and others, 2012). Change in the quantity of sediment stored within each reach bounded by suspended-sediment monitoring stations is now calculated in near real-time. In addition to the quantity of fine sediment entering and exiting each reach via the Colorado River, the tributary inputs of fine sediment must also be quantified to construct these mass balance sediment budgets. The Paria and Little Colorado Rivers are currently the major sources of fine sediment to the Colorado River in GCNP and sediment input from these tributaries is well constrained. The other lesser tributaries described in this report contribute a likely smaller, but perhaps still important, quantity of sand and finer sediment. 
A number of workers have investigated sediment yield to Colorado River from the lesser tributaries. The first such study was completed by the U.S. Department of the Interior, Bureau of Reclamation (Reclamation) in preparation for the construction of Marble Canyon Dam. Reclamation conducted field work in the 1950s, making observations of geology, geomorphology, vegetation, and sedimentation of stock tanks to establish average sediment yield from the lesser tributaries upstream from the proposed dam site (U.S. Department of the Interior, Bureau of Reclamation, 1958). The study concluded that the annual average sediment yield from the lesser tributaries to the Colorado River between the Glen Canyon Dam and the proposed dam site at river mile 32.5 was of $\sim 800,000$ metric tons (including gravel). In (1981), Howard and Dolan published a study in which they estimated the average combined annual sediment yield from the lesser tributaries upstream from the Grand Canyon gage (river mile 87, USGS 09402500) to be 34 percent of the combined contribution of the Paria and Little Colorado rivers, or $\sim 4$ million metric tons (MMT). Randle and Pemberton (1987) used a regional sediment yield regression to calculate lesser tributary annual average sediment yields of $\sim 1.3$ MMT above the Grand Canyon gage. A similar approach was used by Webb and others (2000), who also employed a flood-frequency rating-curve method, and a reservoir sedimentation study combined with a runoff model to calculate three estimates of average annual sediment yield from the lesser tributaries. They estimated an annual sediment yield of 600,000 to 800,000 metric tons above the Grand Canyon gage.

The previous studies calculated average sediment yield and, in many cases, used sediment yield equations that were derived from drainages with substantially different geologic and climatic conditions. The time-averaged nature of the sediment yields calculated from the previous studies make them illsuited for calculation of the shorter time frame sediment budgets needed by river managers for the Colorado River. In 2000, to better constrain the total sediment input from the lesser tributaries, and to improve sediment budgeting for the Colorado River, the U.S. Geological Survey (USGS) Grand Canyon Monitoring and Research Center (GCMRC) established seven suspended-sediment gaging stations on previously ungaged ephemeral tributaries to the Colorado River downstream from Glen Canyon Dam. This network was expanded in 2006 to include the perennial Bright Angel Creek, which has a long-term gaging record beginning in 1923, and is used to provide longer-term hydrologic context to the other lesser tributary stations with much shorter periods of record. Each gaging station consists of a stage recorder and suspended-sediment point sampler(s). Stage is recorded every 15 minutes from a downward-looking ultrasonic stage sensor during zero or base flow conditions, and every minute during flood events. Suspended-sediment samples are collected by passive US U-59 samplers (described in Edwards and Glysson, 1999) and (or) ISCO $^{\mathrm{TM}}$ automatic pump samplers (Teledyne Isco, 2012; Teledyne Isco, 2013).

At each of the gaging stations, channel topography and high-water marks for different peak flows have been surveyed. The approach used to calculate discharge for the surveyed high-water marks is to (1) generate a topographic map and model grid of the stream channel from survey data, (2) perform preliminary model simulations using a "best guess" flood discharge and $Z_{0}$ Nikuradse (1933) bed roughness parameter (based on the measured bed-sediment grain-size distribution) for the first model run, (3) perform successive model runs varying the discharge and $Z_{0}$ to minimize the root-mean-square error between the surveyed high-water marks and the modeled water surface and (4) either hold the established $\mathrm{Z}_{0}$ constant between different flood events or allow $\mathrm{Z}_{0}$ to increase slightly as peak flood stage increases, and model the discharge for different high-water marks to develop stage-discharge relations (Griffiths and others, 2010). Unless the characteristics of the bed change as peak flood stage increases, $Z_{0}$ should remain constant; $Z_{0}$ is only allowed to increase with peak flood stage if there is a physical basis for increasing bed roughness with increasing peak flood discharge (as described herein). Using the stage sensor and suspended-sediment data from each site, total sediment transport can then be determined. 


\section{Purpose and Scope}

This report describes a network of sediment-monitoring gaging stations installed on selected smaller tributaries of the Colorado River in Glen, Marble, and Grand Canyons. The gages were installed to quantify the yield of fine sediment from what were intended to be a representative subset of smaller, or lesser, tributaries to the Colorado River in Glen, Marble, and Grand Canyons. This report provides information on the design and maintenance of this sediment-monitoring gaging network, as well as providing a possible design framework for use on other streams where an accurate measurement of sediment loads is required.

\section{Lesser Tributary Gaging Stations}

There are currently eight gaging stations that automatically measure stage and collect suspendedsediment samples on the lesser tributaries of the Colorado River in lower Glen, Marble, and Grand Canyons (fig. 1). This monitoring network was established in 2000 and expanded in 2006 to include Bright Angel Creek. The major foci of this monitoring network are the ephemeral tributaries of the Colorado River in Marble Canyon. Stage, suspended-silt and clay concentration, suspended-sand concentration, and suspended-sand grain size data are currently collected on lesser tributaries that drain approximately 56 percent of the previously ungaged drainage area of this canyon. All of the lesser tributary sediment-monitoring gaging stations, except for those in Water Holes Canyon and on Bright Angel Creek, monitor streams that drain into Marble Canyon. Water Holes Canyon is an ephemeral tributary of the Colorado River in Glen Canyon and Bright Angel Creek is a perennial tributary of the Colorado River in the Grand Canyon. 


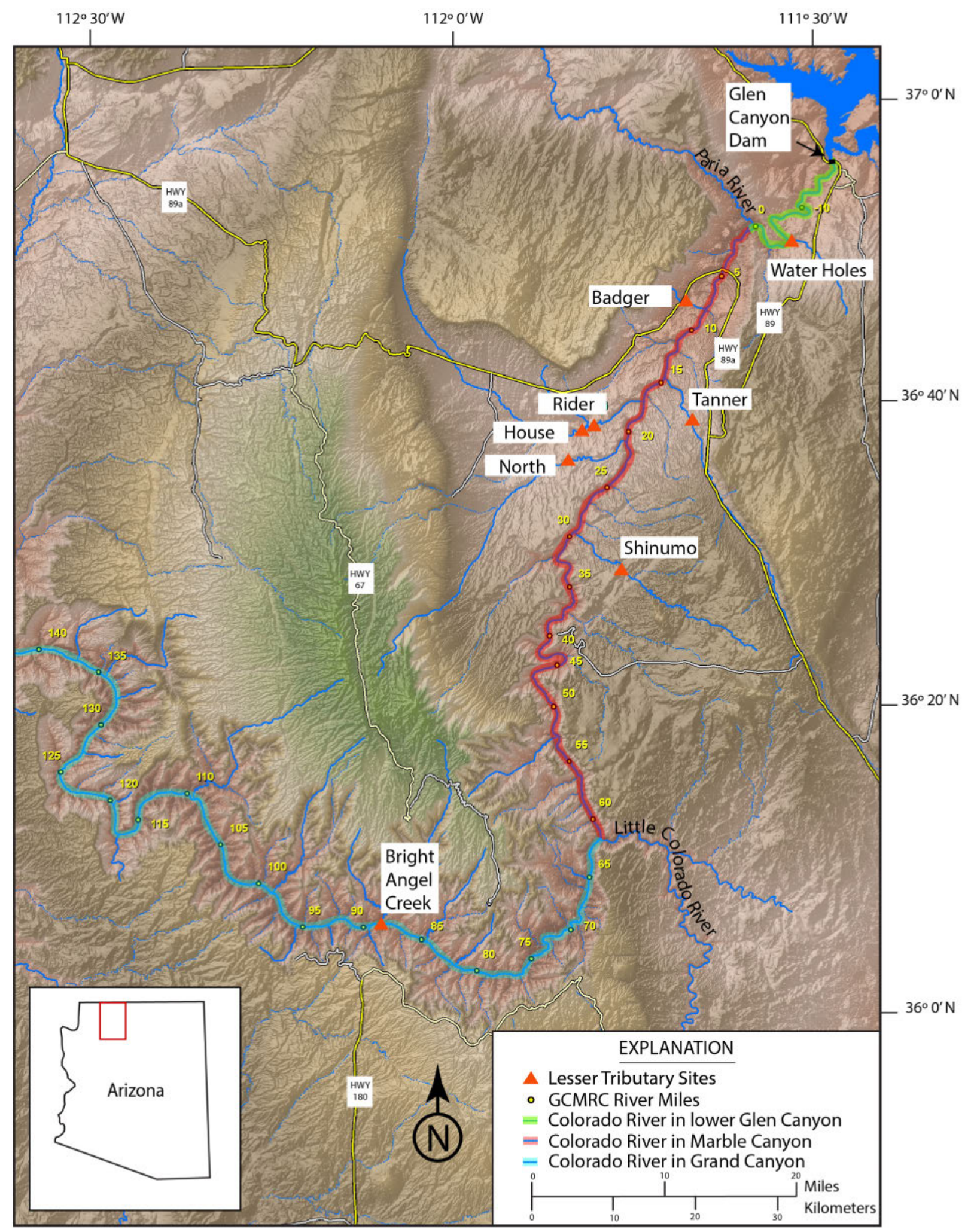

Figure 1. Digital elevation map showing the stage and suspended-sediment gaging stations along the lesser tributaries of the Colorado River, Arizona. Lesser tributary suspended-sediment gaging stations, with informal names in parentheses: Water Holes Canyon (Water Holes), Badger Creek (Badger), Tanner Wash (Tanner), House Rock Wash above Emmett Wash (House), House Rock Wash in Rider Canyon (Rider), North Canyon (North), Shinumo Wash (Shinumo), and Bright Angel Creek. 
The geology of the lesser tributary drainage basins can broadly be split into two groups, areas of high potential fine-sediment yield and areas of lower potential fine-sediment yield. Four of the lesser tributary gaging stations, Water Holes Canyon, Badger Creek, House Rock Wash above Emmett Wash (herein referred to as House Rock Wash), and House Rock Wash in Rider Canyon (herein referred to as Rider Canyon), have drainage basins that are dominated by Mesozoic sandstones and have high potential fine-sediment yields. The active channel streambed of Water Holes Canyon consists of sand on bedrock, with patches of gravel. Badger Creek has a bed dominated by sand and gravel. The bed of House Rock Wash is dominated by sand and fine gravel. The bed of Rider Canyon is composed of patches of sand and gravel on bedrock. The Rider Canyon station has the most comprehensive suspended-sediment record of the lesser tributary gaging stations; at this station, suspended-sediment samples are collected with arrays of US U-59 samplers and an ISCO ${ }^{\mathrm{TM}}$ automatic pump sampler.

North Canyon and Shinumo Wash drain areas that consist primarily of Paleozoic limestone and have lower potential fine-sediment yields. These two tributaries have streambeds that are almost exclusively angular gravel with minor amounts of interstitial sand. The Tanner Wash drainage basin is a combination of high and lower fine-sediment yield areas; the bed of Tanner Wash consists of bedrock, sand, and gravel.

Bright Angel Creek is the only lesser tributary gaging station monitoring a stream that drains into Grand Canyon proper. The Bright Angel Creek drainage basin is dominated by Proterozoic igneous and metamorphic rocks, and Paleozoic limestones, sandstones, and siltstones. Bright Angel Creek at the gaging station section is a steep, cobble-dominated stream with an average base flow of 12-20 cfs. Bright Angel Creek has a historical stream-gaging record from 1923-74 and 1991-93 that provides hydrologic context for the other shorter-record stations. Bright Angel Creek is the only lesser tributary monitored that has a base-flow; all of the other gaged lesser tributaries are ephemeral. Vegetation at the other seven gaging stations consists primarily of sparse, low-lying bushes. The vegetation at the Bright Angel Creek site consists of sparse grasses and sedges along the channel, and small willow and other brush on the upper channel banks.

\section{Generalized Station Design}

Lesser tributary suspended-sediment gaging stations installed and maintained by USGS GCMRC have two main components, several arrays of passive US U-59 single-stage suspended-sediment samplers and a Campbell Scientific SR50 (now replaced by the SR50A-L) downward-looking ultrasonic stage sensor attached to a Campbell Scientific CR10X (now replaced by the CR1000) data logger (fig. 2). Although the SR50 was marketed as a snow depth sensor, it provides a cost-effective, lowmaintenance, and sufficiently accurate downward-looking stage sensor ideal for deployment in the remote locations of these ephemeral tributaries (an overview of techniques used to measure ephemeral stream stage can be found in Bhamjee and Lindsay [2011]). A 12-volt battery attached to a small (10- or 20-watt) charge-controlled solar panel provides power to the SR50 stage sensor and CR10X data logger. Stage is measured and recorded at a 15-min interval during zero- or base-flow conditions, and every minute during flood conditions when the stage is above a user-specified threshold. Two of the lesser tributary gaging stations are equipped with $\mathrm{ISCO}^{\mathrm{TM}}$ automatic pump samplers triggered by liquid-level (stage) actuators. Rain gages are also co-located with all gaging stations. 
A.

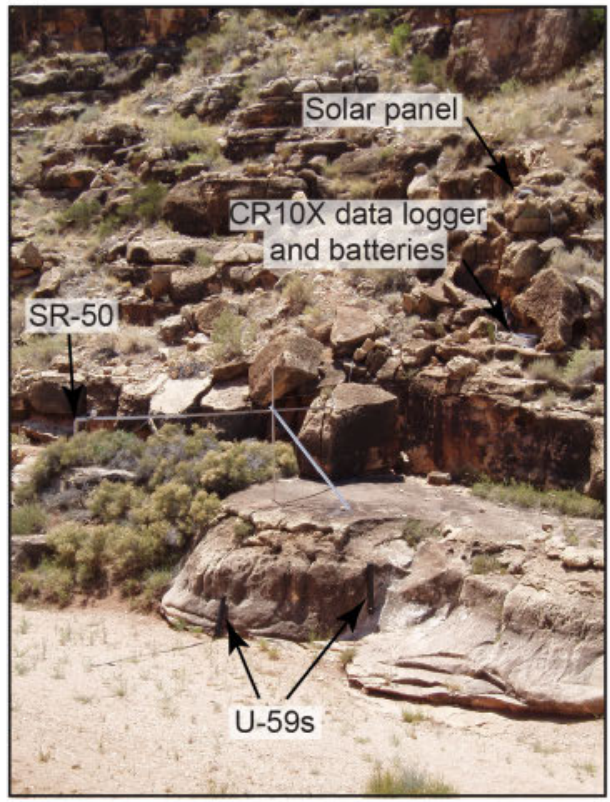

C.

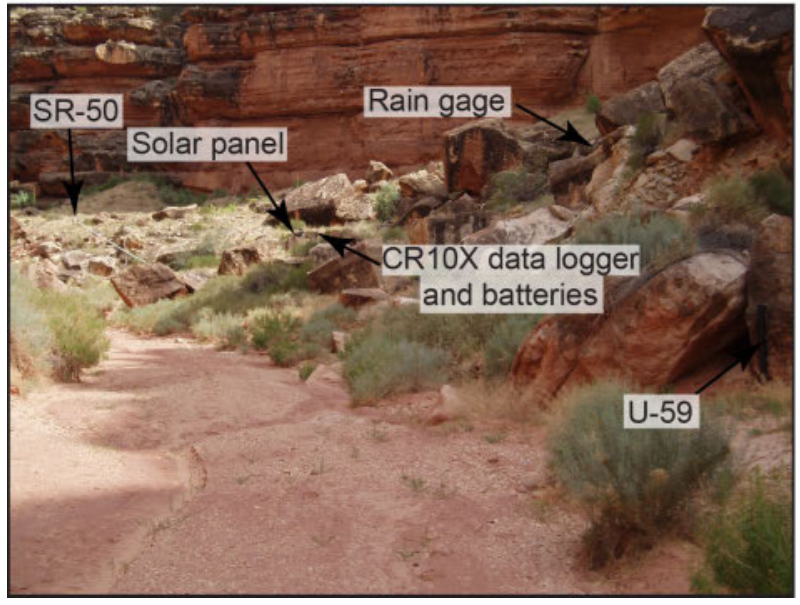

B.

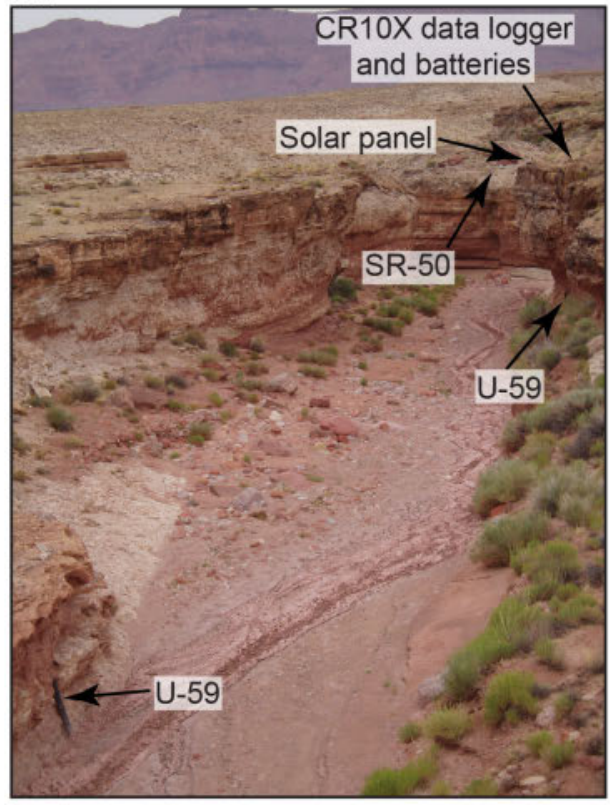

D.

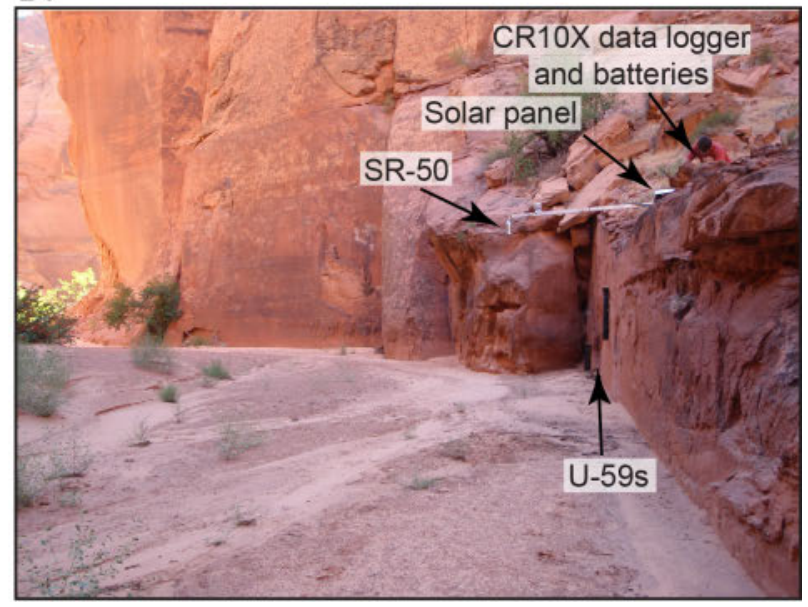

Figure 2. Photographs of gaging stations along the lesser tributaries of the Colorado River, Arizona. $A$, Shinumo Wash station looking across the channel. Station has two arrays of three US U-59s each. The rain gage is located on the opposite stream bank from the station, approximately at the location from where the photograph was taken. B, Badger Creek station looking downstream. Station has two arrays of three US U-59s each. The rain gage is located on the opposite stream bank from the station (to the left of the photograph). $C$, Tanner Wash station looking upstream. Station has two arrays of three US U-59s each; the second array of US U-59s is located behind the point where the photograph was taken. $D$, Water Holes Canyon station looking upstream. Station has two arrays of three US U-59s each. The rain gage is just off the photograph to the right of the station. 


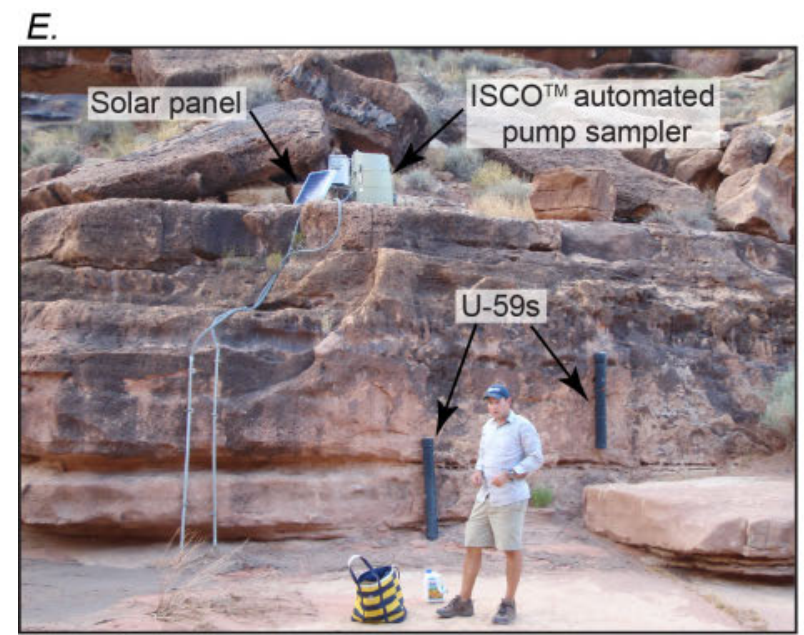

G.

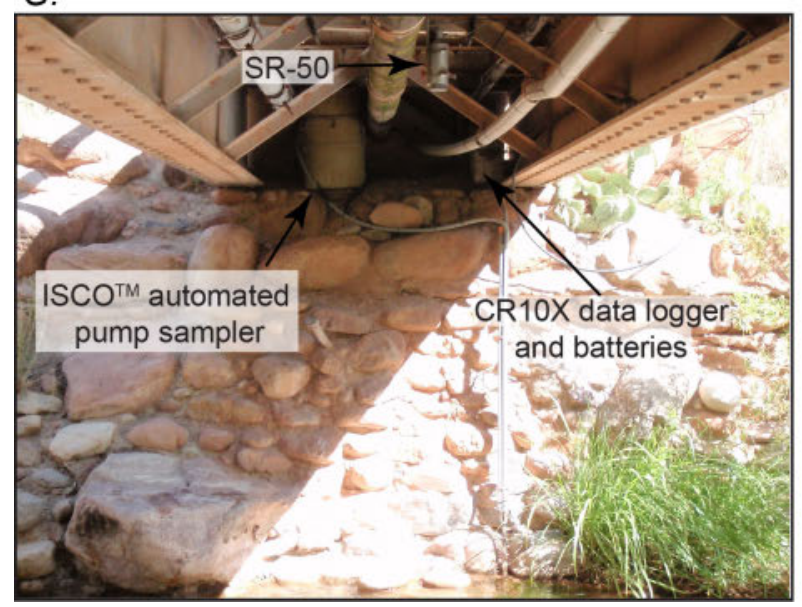

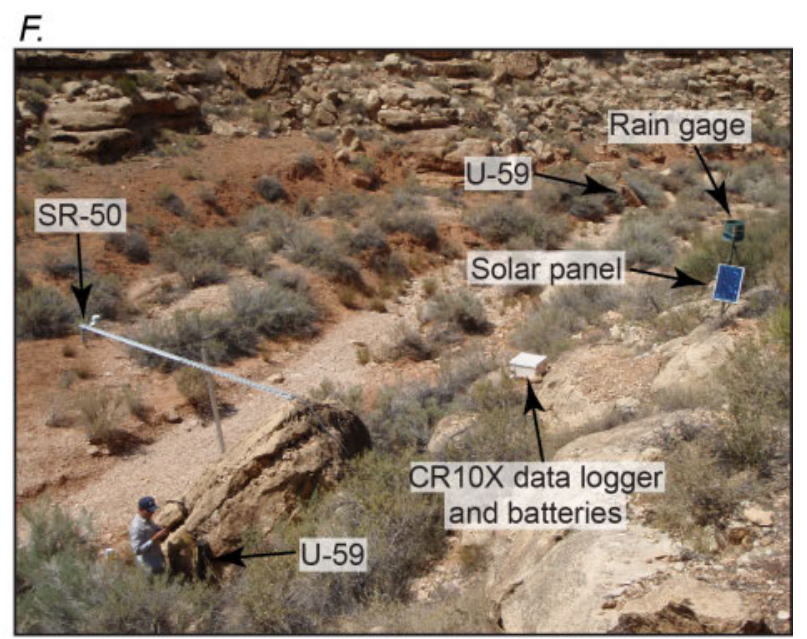

H.

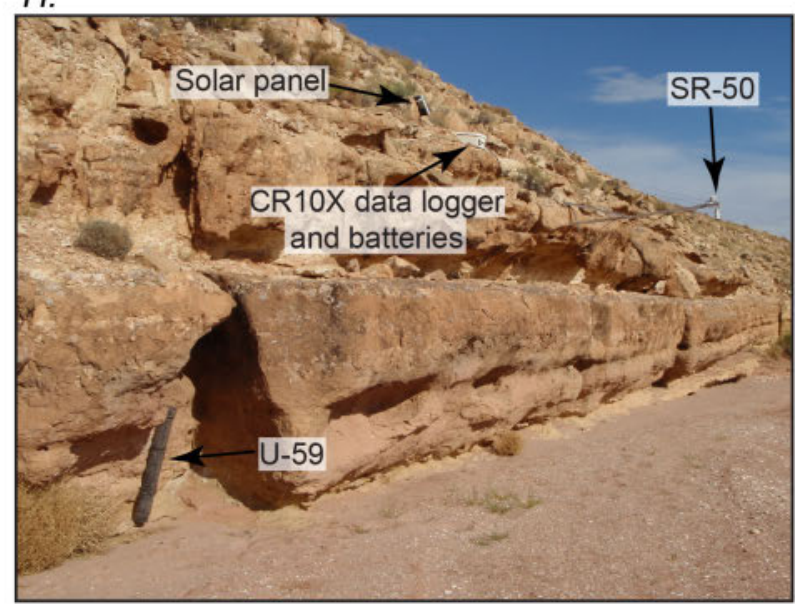

Figure 2. - Continued Photographs of gaging stations along the lesser tributaries of the Colorado River, Arizona. E, Rider Canyon station looking across the channel. Station has three arrays of three US U-59s each. The third array of US U-59s is located $\sim 50 \mathrm{~m}$ upstream (photograph left) of the station. The SR50, CR10X, battery, second solar panel, and rain gage are located on the opposite stream bank from the ISCOTM, just behind where the photograph was taken. $F$, North Canyon station looking downstream. Station has two arrays of three US U-59s each. G, Bright Angel Creek station looking across the stream. The ISCOTM pump sampler, SR50, and CR10X are located under the foot bridge. Power to this station is provided from a National Park Service (NPS) building. A weather station, including a rain gage, is maintained by the NPS several hundred meters upstream. H, House Rock Wash station looking downstream. Station has two arrays of three U-59s each. The second array of US U-59s is located $\sim 50 \mathrm{~m}$ upstream (photograph left) of the station. The rain gage is just off the photograph to the left of the station.

The US U-59 is an inexpensive sampler that requires no power and has no moving parts, making it useful for remote tributaries where visits are infrequent. The US U-59 consists of a sample container, in this case a high-density polyethylene half-liter bottle, attached to an intake hose and an air-exhaust hose (Inter-Agency Committee on Water Resources, Subcommittee on Sedimentation, 1961; Edwards and Glysson, 1999). The intake hose, attached to the sample container with airtight fittings, extends up from the container to the intake nozzle via a gooseneck bend (fig. 3). The intake nozzle is positioned near the top of the sample container. The air-exhaust hose ends several centimeters above the bottom of the sample container. During tributary floods, suspended-sediment sample flows into the container when 
the stream stage increases above the top of the gooseneck bend in the intake hose. The flow into the sample container stops when the pressure inside the sample container increases because the rising flood blocks the exhaust hose. An ABS (acrylonitrile butadiene styrene) pipe, in which an access hatch has been cut, typically houses three US U-59 samplers (fig. 3). Arrays of samplers are bolted to boulders or the canyon wall (fig. 2). Two or three arrays of samplers are bolted at progressively higher elevations to allow samples to be collected as the stage increases.

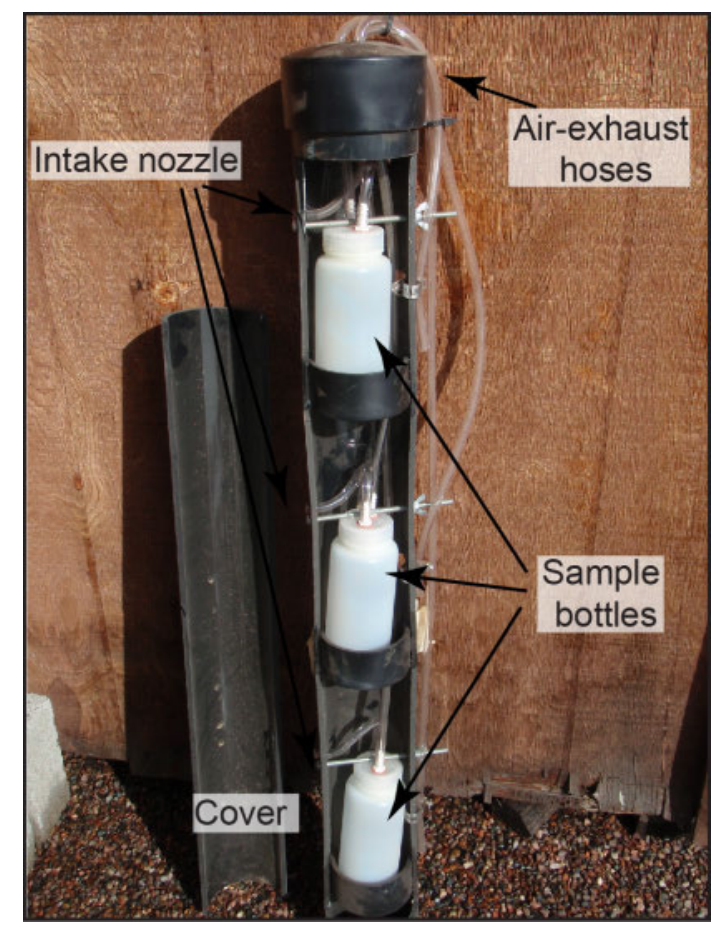

Figure 3. A U-59 single-stage suspended-sediment sampler. Bolts, secured with wing nuts, keep the sample containers in place during flood events along the lesser tributaries of the Colorado River, Arizona. Cable (zip) ties attach the cover and keep the air exhaust hoses in place.

Although US U-59 samplers are cheap and easy to use, problems with sampler operation frequently occur. Problems with US U-59 samplers are mostly related to the correct filling of the sample container

- The sample bottle may not fill properly because of the small size of the intake hose $(0.635 \mathrm{~cm}$ inside diameter).

- Waterborne debris or insects may clog the intake hose.

- The intake hose may become crimped with age.

- The intake hose may fill with windblown sand during the long periods between flood events.

- The rising limb of a flood may rise too fast, blocking the exhaust port before a water sample is collected.

- The sample container may overfill or collect multiple samples because of a pulsating flood, multiple floods between station visits, or as a result of an air leak in the system.

In addition, if the samplers are located in areas of high stream velocity, the current may tear them from the securing bolts during extreme flow events. These problems cause a high rate of sample collection failure, which, given the low expense and ease of use, is acceptable at many locations. Sediment-monitoring gaging stations where more reliable sampling is required (Rider Canyon and Bright Angel Creek) have ISCO ${ }^{\mathrm{TM}}$ automatic pump samplers (table 1). The $\mathrm{ISCO}^{\mathrm{TM}}$ pump samplers hold 
24 sample collection bottles. The pump samplers, secured above the foreseeable high-flow stage, have a sample tube and a liquid level actuator that extend down to $\sim 30-40 \mathrm{~cm}$ above the channel bed. When water rises above the elevation of the liquid actuator, the pump samplers collect suspended-sediment samples at a programmed interval until the water recedes and the actuator dries. The pump sampler and the US U-59 sampler are both point samplers. Analyses of samples collected in similar gradient and sediment-concentration streams (for example, the Paria River) have shown that point samples, automated pump samples, and dip samples are usually equivalent to more-accurate depth-integrated samples in these types of streams where suspended sand, silt, and clay are typically well mixed in the cross section.

Table 1. Equipment present at each sediment-monitoring gaging station along the lesser tributaries of the Colorado River, Arizona.

\begin{tabular}{|c|c|c|c|c|}
\hline $\begin{array}{l}\text { Station } \\
\text { name }\end{array}$ & $\begin{array}{l}\text { SR50 ultrasonic stage } \\
\text { sensor }\end{array}$ & Arrays of U-59s & $\begin{array}{l}\text { ISCOTM pump } \\
\text { sampler }\end{array}$ & Rain gage \\
\hline Water Holes Canyon & $\mathrm{X}$ & 2 arrays of 3 & & $\mathrm{X}$ \\
\hline Badger Creek & $\mathrm{X}$ & 2 arrays of 3 & & $\mathrm{X}$ \\
\hline Tanner Wash & $\mathrm{X}$ & 2 arrays of 3 & & $\mathrm{X}$ \\
\hline House Rock Wash & $\mathrm{X}$ & 2 arrays of 3 & & $\mathrm{X}$ \\
\hline Rider Canyon & $\mathrm{X}$ & 3 arrays of 3 & $\mathrm{X}$ & $\mathrm{X}$ \\
\hline North Canyon & $\mathrm{X}$ & 2 arrays of 3 & & $\mathrm{X}$ \\
\hline Shinumo Wash & $\mathrm{X}$ & 2 arrays of 3 & & $\mathrm{X}$ \\
\hline Bright Angel Creek & $\mathrm{X}$ & 0 & $\mathrm{X}$ & $\mathrm{X}$ \\
\hline
\end{tabular}

Stage is measured at the stations with a downward-looking Campbell Scientific SR50 ultrasonic sensor attached to a Campbell Scientific CR10X data logger. (See Appendix 1 for a wiring diagram and programming instructions.) The data logger records stage measurements every 15 minutes during background conditions and every minute during flood conditions. The recording interval changes to one minute when the sensor detects that the stage has risen past a pre-programmed level (usually $0.1-0.2 \mathrm{~m}$ above the elevation of the dry bed).

To provide meteorological context for flood events and provide insight into sediment sources, rain gages were installed in each of the monitoring station drainage basins. A total of 29 tipping-bucket rain gages (fig. 4) were installed with rain gages co-located with each of the sediment gaging stations and typically 2 rain gages installed upstream from each station. The tipping-bucket rain gages are connected to $\mathrm{HOBO}^{\mathrm{TM}}$ event loggers that are powered by internal batteries. Rain gaging sites are visited every six months to collect data and replace batteries. It is anticipated that data from this rain-gage network will provide insight into the amount of sediment likely to be supplied from these tributaries during future storm events. 


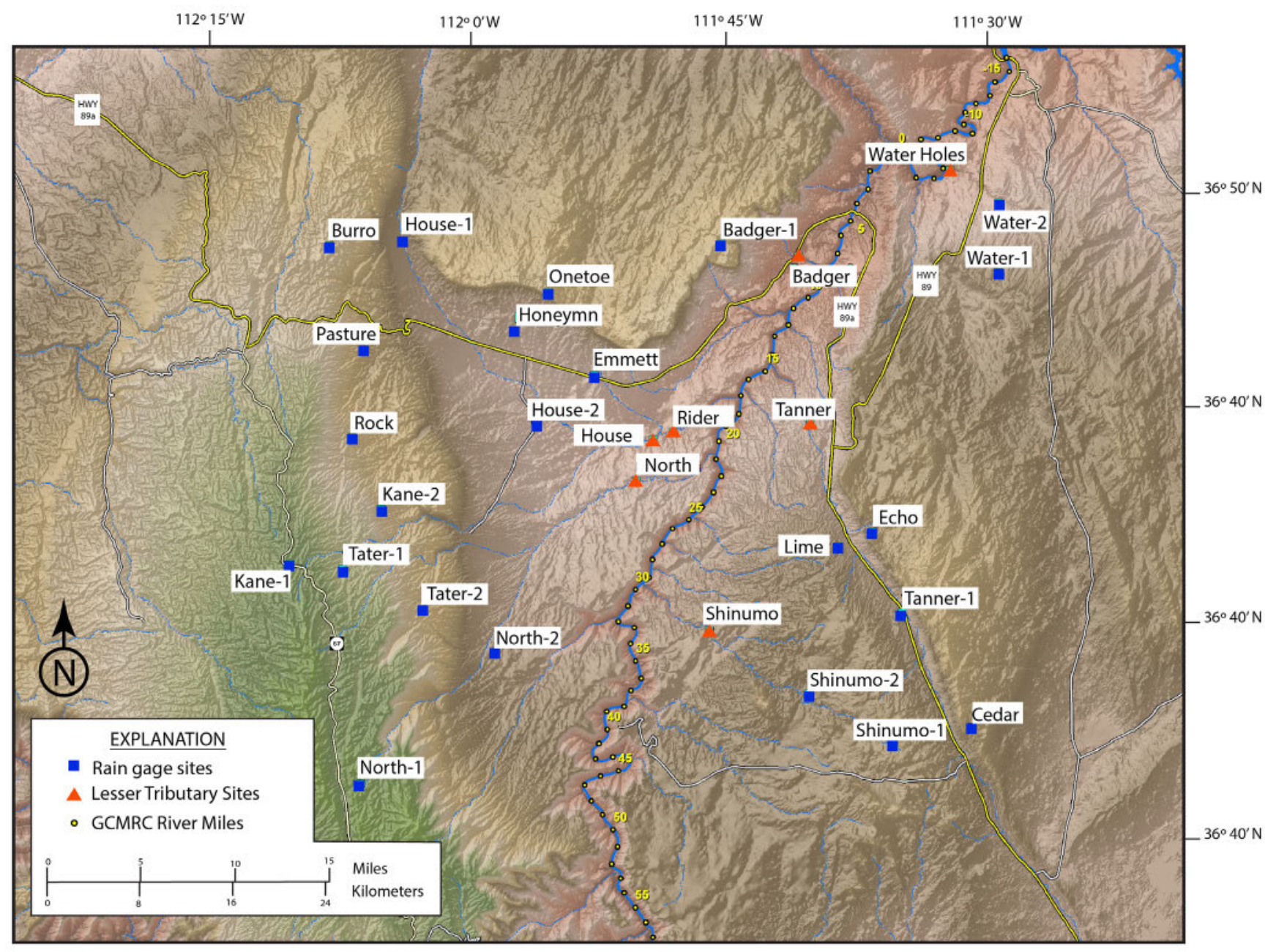

Figure 4. Digital elevation map showing the rain-gage network surrounding the lesser tributaries of the Colorado River, Arizona.

\section{Station Placement Considerations}

The placement of tributary sediment-monitoring gaging stations directly affects the quality of data collected and amount of maintenance required at any given site. Where to place the station along the tributary is the first consideration. This decision affects the percentage of the tributary system sampled, the frequency of human foot traffic past the station, and the ease of access to the station for maintenance. The easier a site is to access, the more likely it is that the site will be vandalized. An extremely remote site, while safe from vandals, will increase the time and effort required for maintenance. Most of the GCMRC stations are located a short hike, less than a half hour, from infrequently used dirt roads. The compromise between remoteness and ease of access allows a technician to service several stations a day and, at the same time, reduces vandalism.

Once a general location is identified, a specific station site must be chosen. An ideal station location features several hours of direct sunlight during all times of the year (for charging batteries), a stable channel near a steep wall or large boulder (above any anticipated high water), a relatively straight and uniform channel upstream and downstream (for ease of modeling discharge), and several locations to bolt US U-59 samplers. The downward-looking ultrasonic sensor should be mounted directly over a stable part of the channel. This is accomplished at the GCMRC stations by mounting the sensor on an 
aluminum L-beam that is anchored to the wall or boulder with anchor bolts and guide wires (fig. 2). Though it is clearly important to install the stage sensor above the maximum anticipated stage, problems can be caused by mounting the sensor too high above the streambed. The Campbell Scientific SR50 ultrasonic sensor attached to a Campbell Scientific CR10X data logger used at USGS GCRMC sediment-monitoring gaging stations will not record data when the sensor is mounted more than $10 \mathrm{~m}$ above the channel surface. In addition, a higher sensor mount increases the footprint of the ultrasonic beam, producing noisier data and a greater chance of beam inference. To ease the modeling of flood events, and to develop a stage-discharge relation for the station, the channel near the station should be uniform. Stations with large changes in channel roughness or channel width, or that have tight bends, will result in poor discharge modeling. Because of the difficulty in meeting all of these requirements in one compact location, several of the USGS GCMRC stations have equipment that is spread out over tens of meters along the channel (fig. 2).

\section{Discharge Calculations}

The remote location of the stations coupled with the short duration of flood events makes it very difficult and potentially expensive to measure the discharge of water directly. Discharge of water during floods is therefore modeled using the USGS National Research Program multidimensional surface water modeling system (McDonald and others, 2005) and the quasi-three-dimensional flow and sediment transport with morphological evolution of channels solver. The approach used is to

1. Select a suitable reach for modeling and complete a base topographic survey. A suitable channel reach is stable and relatively straight. The simple channel geometry will result in an easier flow modeling process. During the initial survey the position of the stage sensor and any suspendedsediment sampler intakes should also be recorded.

2. Survey multiple sets of high-water marks within the reach corresponding to floods with different peak stages. A wide range of high-water marks from flood peak stage will allow the development of a comprehensive stage-discharge relation.

3. Generate a topographic map and model grid of the stream channel from survey data. Survey cross sections are typically collected every 2-3 $\mathrm{m}$ along the channel.

4. Enter a "best guess" flood discharge and $\mathrm{Z}_{0}$ roughness parameter (based on the bed-sediment grain-size distribution) for the first model run.

5. Perform successive model runs varying the discharge and $Z_{0}$ to minimize the root-mean-square error between the surveyed high-water marks and the modeled water surface.

6. Attempt to hold the established $\mathrm{Z}_{0}$ constant in the model, and model the discharge associated with different high-water marks to develop stage-discharge relations (Griffiths and others, 2010).

7. Only allow $Z_{0}$ to increase with increasing peak flood stage if there is physical evidence that the roughness characteristics of the bed change with increasing stage, as described below.

The Nikuradse (1933) $Z_{0}$ bed roughness parameter is used for flow modeling. This roughness parameter was chosen instead of the more commonly used Manning's n roughness parameter because, unlike the Manning's $n$ roughness parameter, $Z_{0}$ does not depend on stage and only depends on the characteristics of the bed. As discharge increases in gravel-bedded rivers $Z_{0}$ should remain constant unless the gravel bed becomes fully mobile or rougher areas of the bed and banks become inundated. As either vegetated or formerly dry rougher areas of the bed, banks, and canyon walls become inundated and added to the model grid, $\mathrm{Z}_{0}$ increases. For an immobile gravel bed, $\mathrm{Z}_{0}$ is approximately equal to 0.1 D84 (Whiting and Dietrich, 1989; Wiberg and Smith, 1991), where D84 is the 84th percentile grain size of the gravel. As the gravel bed becomes fully mobile, $\mathrm{Z}_{0}$ increases to approximately equal $0.5 D 84$ (Pitlick, 1992) 
Modeled peak flood discharges are combined with the corresponding SR50 recorded stages to develop a stage-discharge relation for the site. This stage-discharge relation is used for all subsequent floods unless major changes in the channel geometry are observed. If significant channel changes occur, a new stage discharge relation must be developed using the steps above. Where an insufficient number and diversity of floods have been modeled to develop a good stage-discharge relation, any high-water marks observed during maintenance visits to the station are flagged for later survey.

\section{Station Visits and Maintenance}

Stations are visited twice a year for general maintenance. Additional visits may occur after significant precipitation or flood events. The majority of run-off events on the lesser tributaries occur during the southwest monsoon season (July-September). National Weather Service radar is monitored daily during this time to provide a precipitation alert and to allow field technicians the opportunity to service the suspended-sediment samplers before the next run-off event. Maintenance completed during regularly scheduled biannual site visits includes the following

- downloading the CR10X data logger and the $\mathrm{HOBO}^{\mathrm{TM}}$ event logger using the vendor provided software (Appendix),

- replacing the $\mathrm{HOBO}^{\mathrm{TM}}$ event logger internal battery,

- checking the accuracy of the tipping bucket rain gage,

- checking for samples in the U-59 samplers and inspecting the condition of the samplers,

- checking the ISCO ${ }^{\mathrm{TM}}$ (if present) for samples and correct operation,

- load testing the station's 12-volt battery, and

- inspecting the station for rodent and other damage.

Common issues that can arise at stations include the following

- damage to the U-59 samplers due to extreme flow events,

- sun damage (UV) to the U-59 bottles and intake hoses,

- vandalism and theft of parts (mainly batteries and solar panels),

- rodent damage to wiring,

- growth of plants blocking the solar panel, and (or)

- growth of plants in the channel, interfering with the Campbell Scientific SR50 ultrasonic sensor signal.

\section{Summary}

A suspended-sediment monitoring gaging network has been established for remote ephemeral tributaries to the Colorado River downstream from Glen Canyon Dam. This monitoring network is comprised of eight gaging stations, each of which measures stage and collects suspended-sediment samples during flood events. Stage-discharge relations for the gaging stations are developed using a numerical flow model to determine discharge for several sets of flood high water marks. Modeled discharges are matched with the record of stage for a station to develop the stage discharge relation. Stage-discharge relations are used in conjunction with stage record and suspended-sediment data to compute sediment loads; sediment loads are the product of discharge and suspended-sediment concentration. Prior to the establishment of this gaging network, only relatively crude and likely highly inaccurate estimates of the sediment input from the lesser tributaries in lower Glen, Marble, and Grand Canyons to the Colorado River existed. The ability to calculate sediment loads in the lesser tributaries made possible by this gaging network is providing much-needed information on the relative importance of these tributaries in supplying sediment to the Colorado River in both Glen Canyon National Recreation Area and Grand Canyon National Park. Furthermore, the methods developed herein are 
transferrable and can easily be employed to compute discharge and sediment loads at other remote locations where information on discharge and sediment loads is needed.

\section{Acknowledgments}

This project was funded by the U.S. Department of the Interior's Glen Canyon Dam Adaptive Management Program through the USGS Grand Canyon Monitoring and Research Center. Susannah Erwin and David Dean both provided thoughtful reviews that improved the quality of this report.

\section{References Cited}

Bhamjee, R., and Lindsay, J.B., 2011, Ephemeral stream sensor design using state loggers: Hydrology and Earth System Sciences, v. 15, p. 1009-1021.

Campbell, D., Durst, S., Kantola, A.T., Kubly, D.M., Muth, R.T., Swett, J., and Whitmore, S., 2010, Overview of the Colorado River Basin collaborative management programs, in Melis, T.S., Hamill, J.F., Bennett, G.E., Coggins, L.G., Jr., Grams, P.E., Kennedy, T.A., Kubly, D.M., and Ralston, B.E., eds., Proceedings of the Colorado River Basin science and resource management symposium, November 18-20, 2008, Scottsdale, Ariz.: U.S. Geological Survey Scientific Investigations Report 2010-5135, p.15-42. [Also available at http://pubs.usgs.gov/sir/2010/5135/.]

Coppus, R., and Imeson, A.C., 2002, Extreme events controlling erosion and sediment transport in a semi-arid sub-Andean valley: Earth Surface Processes and Landform, v. 27, p. 1365-75.

Edwards, T.K., and Glysson, G.D., 1999, Field methods for measurement of fluvial sediment: U.S. Geological Survey Techniques of Water-Resources Investigations, book 3, chap. C2, 89 p. [Also available at http://pubs.usgs.gov/twri/twri3-c2/.]

Graf, W.L., 1983, Variability of sediment removal in a semiarid watershed: Water Resource Research, v. 19 , p. 643-652.

Griffiths, R.E., Topping, D.J., Andrews, T., Bennett, G.E., Sabol, T.A., and Melis, T.S., 2012, Design and maintenance of a network for collecting high-resolution suspended-sediment data at remote locations on rivers, with examples from the Colorado River: U.S. Geological Survey Techniques and Methods, book 8, chap.C2, 44 p.

Griffiths, R.E., Topping, D.J., McDonald, R.R., and Sabol, T.A., 2010, The use of the multidimensional surface-water modeling system (MD_SWMS) in calculating discharge and sediment transport in remote ephemeral streams in Conference on Sedimentation and Hydrologic Modeling, Las Vegas, Nev., June 27-July 1, 2010, Proceedings: Joint Federal Interagency Conference, 12 p.

Howard, A.D., and Dolan, R., 1981, Geomorphology of the Colorado River in the Grand Canyon: Journal of Geology, v. 89, p. 269-298.

Inter-Agency Committee on Water Resources, Subcommittee on Sedimentation, 1961, The single-stage sampler for suspended-sediment in A study of methods used in the measurement and analysis of sediment loads in streams: Interagency Report no. 13, 105 p.

McDonald, R.R., Nelson, J.M., and Bennett, J.P., 2005, Multi-dimensional surface-water modeling system user's guide: U.S. Geological Survey Techniques and Methods, Book 6 Chapter B2, 132 p.

Nikuradse, J., 1933, Laws of flow in rough pipes: VDI-Forschungsheft, no. 361. [In German, translation NACA Tech Memo, no. 1292, 62 p.]

Pitlick, J., 1992, Flow resistance under conditions of intense gravel transport: Water Resources Research, v. 28, p. 891-903.

Randle, T.J., and Pemberton, E.L., 1987, Results and analysis of STARS modeling efforts of the Colorado River in Grand Canyon: Glen Canyon Environmental Studies Report, 41 p. 
Rank1, J.G., 2002, Relations between total-sediment load and peak discharge for rainstorm runoff on five ephemeral streams in Wyoming: U.S. Geological Survey Water-Resources Investigations Report 02-4150, $12 \mathrm{p}$.

Schick, A.P., 2000, A brief summary of a third of a century-Nahal Yael in retrospect, with some ideas for the future of catchment research: Proceedings of the Jerusalem Conference, Jerusalem, Israel, May 1999 , p. 5-9.

Schick, A.P., and Lekach, J., 1996, Storage versus input-output actuary — an evaluation of two ten-year sediment budgets, Nahal Yael, Isreal: Physical Geography, v. 14, p. 225-236.

Schmidt, J.C., Topping, D.J., Grams, P.E., and Hazel, J.E., Jr., 2004, System-wide changes in the distribution of fine sediment in the Colorado River corridor between Glen Canyon Dam and Bright Angel Creek, Ariz.: Final report to the USGS Grand Canyon Monitoring and Research Center, Flagstaff, Arizona, 107 p.

Sharma, K.D., and Murthy, J.S., 1994, Modeling sediment transport in stream channels in the arid zone of India: Hydrological Processes, v. 8, p. 567-572.

Sharma, K.D., Vangani, N.S., and Choudhari, N.S., 1984, Sediment transport characteristics of the desert streams in India; Journal of Hydrology, v. 64, p. 261-272.

Sutherland, R.A., and Bryan, K.B., 1990, Runoff and erosion from a small semiarid catchment, Baringo district, Kenya: Applied Geography, v. 10, p. 91-109.

Teledyne Isco, 2012, Isco 6712 Full-size Portable Sampler: Lincoln, Nebr., Teledyne Isco Inc., Isco product data, revised 12/12, 2 p., accessed on January 2, 2014 at http://www.isco.com/WebProductFiles/Product_Literature/201/Portable_Samplers/FullSize_Portable SSamplers/6712_Fullsize_Portable_Sampler.p $\overline{d f}$,.

Teledyne Isco, 2013, Isco 6712 Portable Samplers Installation and Operation Guide: Lincoln, Nebr., Teledyne Isco Inc., 6712 Portable Sampler User Manual, Revision FF, revised October 2013, 244 p., accessed on January 2, 2014 at http://www.isco.com/pcfiles/PartPDF/SL000005/UP001ART.pdf.

Topping, D.J., Melis, T.S., Rubin, D.M., and Wright, S.A., 2004, High-resolution monitoring of suspended-sediment concentration and grain size in the Colorado River in Grand Canyon using a laser-acoustic system, in $\mathrm{Hu}, \mathrm{C}$., and Tan, Y., eds., Proceedings of the Ninth International Symposium on River Sedimentation, October 18-21, 2004, Yichang, China, v. 4, p. 2507-2514. [Also available at http://www.gcmrc.gov/library/reports/Physical/Fine_Sed/Topping2004.pdf.]

U.S. Department of the Interior, Bureau of Reclamation, 1958, Office Memorandum from W.V Turner and S.H. Robeson, September 16, 1958.

Walling, D.E., 1977, Assessing the accuracy of suspended sediment rating curves for a small basin: Water Resources Research, v. 13, p. 531-538.

Webb, R.H., Griffiths, P.G., Melis, T.S., and Hartley, D.R., 2000, Sediment delivery by ungaged tributaries of the Colorado River in Grand Canyon, Arizona: U.S. Geological Survey Water-Resources Investigations Report 00-4055, 67 p.

Whiting, P.J., and Dietrich, W.E., 1989, The roughness of alluvial surfaces; an empirical examination of the influence of size heterogeneity and natural packing [abs.]: EOS Transactions, American Geophysical Union, v. 70, p. 1109.

Wiberg, P.L., and Smith, D.J., 1991, Velocity distribution and bed roughness in high-gradient streams: Water Resources Research, v. 27, p. 825-838.

Wolman, M.G., and Miller, J.P., 1960, Magnitude and frequency of forces in geomorphic processes: Journal of Geology, v. 68, p. 54-74. 


\section{Appendix: Campbell Scientific CR10X, SR50, and Onset Rain Gage}

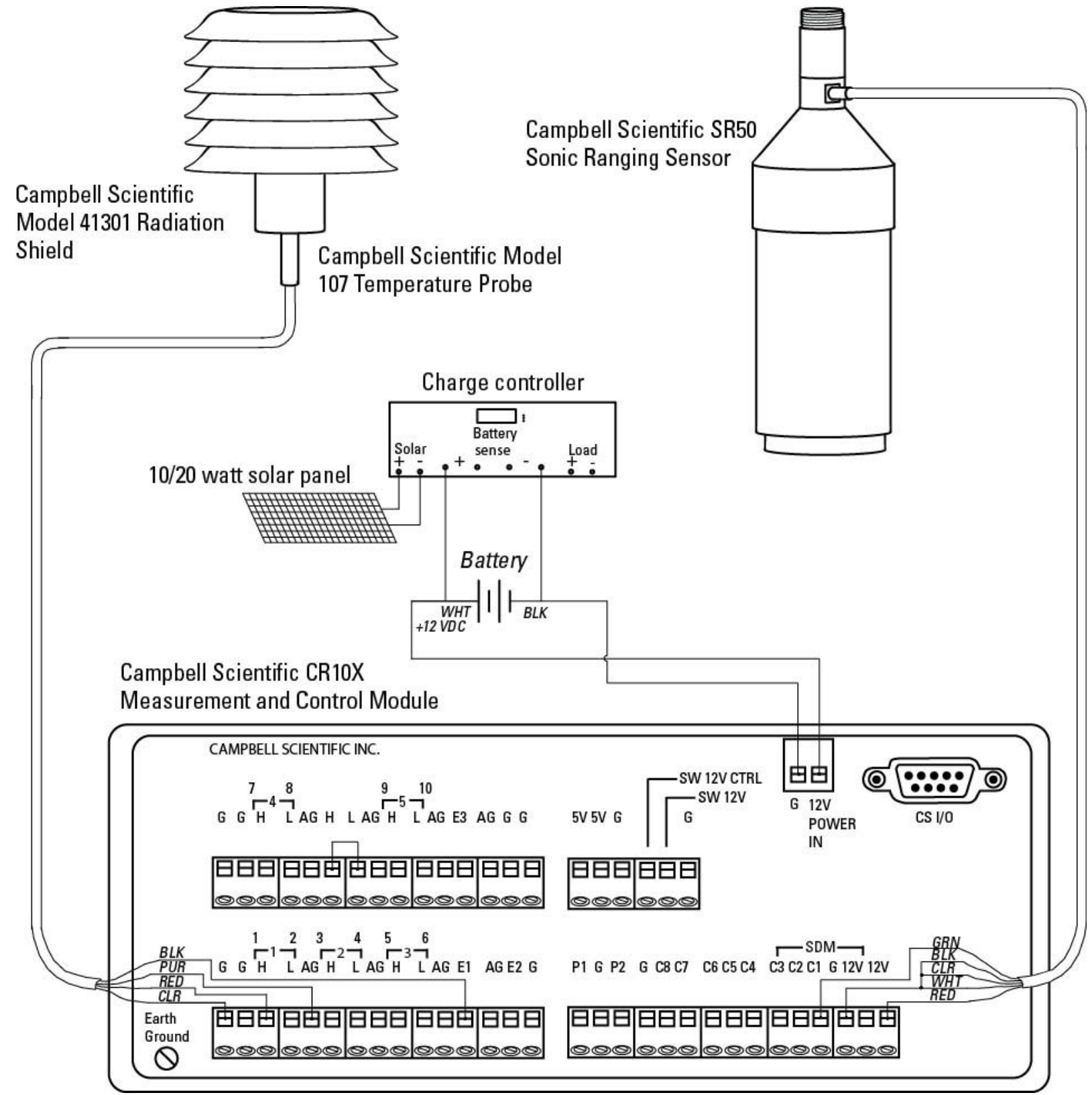

Wiring connection diagram of the tributary gaging station Campbell Scientific CR10X datalogger and SR50 stage sensor. The wiring of specific data loggers may differ from the one depicted; wiring ports with the same label may be used interchangeably. 


\section{CR10X instructions}

Instructions for setup of PC208W 3.3 so only data collected since last visit are downloaded

Each station must have a uniquely named device/CR10X data logger in the "Station List" in the datalogger connection window.

1. To set up a unique station name in PC208W open "Setup" (first button in, has an icon of a phone/power line) from the "PC208W 3.3-Datalogger Support Software" window.

2. Select the "Add Device" button.

3. A window will open asking to select type of device to be added, select "CR10X Datalogger", and click "ok".

4. In the "Setup Connections" window, next to "CR10X Datalogger Name" name the station.

5. Under the "Data Collection" tab (tabs are on the bottom of the window) make sure the following options have been selected

- Collect - Data logged since last call

- File Mode - Append to end of file

- File Format - ASCII, comma separated

- If large data files are to be downloaded, check under the "Hardware" tab and change the "Maximum Time On-line (sec)" to provide sufficient time to complete downloads; downloading six months of data can take more than an hour if significant 1-min intervals of data have been collected.

- Click the "Save Edits" button and close "Setup Connections" window.

\section{CR10X program}

; $\{$ CR 10$\}$

*Table 1 Program

01: 60.0000 Execution Interval (seconds)

1: Temp (107) (P11)

1: 1 Reps

2: 1 SE Channel

3: 1 Excite all reps w/Exchan 1

4: 1 Loc [Temp_K]

5: 1.0 Mult

6: 273.15 Offset

2: SDI-12 Recorder (OS10 1.1) (P105)

1: 0 SDI-12 Address

2: 1 Start Measurement (aM1!)

3: 1 Port

4: 2 Loc [Dist_m]

5: 1.0 Mult

6: 0.0 Offset

3: Batt Voltage (P10)

1: 6 Loc [Batt_Volt]

4: $\mathrm{Z}=\mathrm{F}(\mathrm{P} 30)$

1: $2.4 \mathrm{~F}$

2: 00 Exponent of 10 
5: $\mathrm{Z}=\mathrm{F}(\mathrm{P} 30)$

1: $0.01 \mathrm{~F}$

2: 00 Exponent of 10

3: 8 Z Loc [Minimum_m]

6: $\mathrm{Z}=\mathrm{F}(\mathrm{P} 30)$

1: $273.15 \mathrm{~F}$

2: 0 Exponent of 10

3: 3 Z Loc [RefTemp_K]

7: $\mathrm{Z}=\mathrm{X} / \mathrm{Y}(\mathrm{P} 38)$

1: 1 X Loc [Temp_K]

2: 3 Y Loc [RefTemp_K]

3: 4 Z Loc [Mult]

8: $\mathrm{Z}=\mathrm{SQRT}(\mathrm{X})(\mathrm{P} 39)$

1: 4 X Loc [Mult]

2: 4 Z Loc [Mult]

9: $Z=X^{*} Y(P 36)$

1: 2 X Loc [Dist_m]

2: 4 Y Loc [Mult]

3: 5 Z Loc [TCDist_m]

10: If time is (P92)

1: 0 Minutes (Seconds --) into a

2: 15 Interval (same units as above)

3: 10 Set Output Flag High

11: Real Time (P77)

1: 120 (Same as 220) D,Hr/Mn

12: Sample (P70)

1: 1 Reps

2: 1 Loc [Temp_K]

13: Sample (P70)

1: 1 Reps

2: 5 Loc [TCDist_m]

14: If $(\mathrm{X}<=>\mathrm{Y})(\mathrm{P} 88)$

1: 5 X Loc [TCDist_m]

2: $3>=$

3: 8 Y Loc [Minimum_m]

4: 30 Then Do

15: If $(\mathrm{X}<=>\mathrm{Y})$ (P88)

1: 5 X Loc [TCDist_m]

2: $4<$;

3: 7 Y Loc [Thresh_m]

4: 30 Then Do

16: Do (P86)

1: 10 Set Output Flag High

17: Real Time (P77)

1: 120 (Same as 220) D,Hr/Mn

18: Sample (P70)

1: 1 Reps

2: 1 Loc [Temp_K] 
19: Sample (P70)

1: 1 Reps

2: 5 Loc [TCDist_m]

20: End (P95)

21: End (P95)

22: Serial Out (P96)

1: 71 SM192/SM716/CSM1

*Table 2 Program

01: 0.0000 Execution Interval (seconds)

*Table 3 Subroutines

End Program

\section{Instructions for downloading the CR10X datalogger}

1. Open "PC208W v3.3" and click the "Real-time connection to datalogger" button (second button in, has an icon of a computer connected to an instrument) from the "PC208W 3.3-Datalogger Support Software" widow. A new window "Datalogger Connection" will open.

2. Under the "Station List" select the station to be downloaded.

3. Click the "connect" button.

4. Make sure that the "Manual Data Collection" box for "Prompt for data file name" is checked.

5. Set the instrument clock by clicking the "Set Datalogger Clk" button.

6. Click the "COLLECT" button, this will download all data logged since the last station visit; browse for the correct save location and name the file.

7. After the data is downloaded click the "Numeric" button and check that the program for the station is still set up appropriately for the current conditions.

8. Under Numeric, make sure that the threshold value for "Inloc_5" / "TCDist_m" (temperature corrected distance) is 0.1-0.2 meters greater than the value for "Inloc 7" / "Thresh_m" (threshold distance). If the row titles are shown as Inloc_\# the proper titles can be displayed by first using the "Associate DLD Program" button and selecting the appropriate station program (found under $\backslash \mathrm{PC} 208 \mathrm{~W} \backslash \mathrm{CSIPRO} 1$ ).

- If the threshold value is not correct, the program must be changed and reloaded.

- From the "PC208W 3.3-Datalogger Support Software" widow click the "Edit datalogger program with Edlog" button (fourth button in, has an icon of a keyboard).

- Edit the value displayed on line 4: 1: to the appropriate distance (the threshold should be LESS than the TCDist); this is the threshold beyond which the instrument will begin logging 1-min data.

- Save the file, when the confirm window pops up click "yes" compile program.

- There should be no errors, click "yes" again.

- Open the numeric window to check that the threshold has been set correctly. NOTE: it may take several minutes for the new values to appear in the numeric window.

Once finished, close the window and PC208W, the datalogger is always running and does not need to be launched. 
Instructions on deleting all data stored on the CR10X

Only follow these directions if all data has been backed up and you want to permanently delete all data stored on the datalogger. This option may be useful if the computer used for downloading the datalogger will change. The information on the last download date is stored on the download computer, if a new computer is used the entire datalogger will be downloaded.

1. Open "PC208W v3.3" and open the "Datalogger Connection" window by clicking the "Real-time connection to datalogger" button.

2. Under the "Station List" select the name of the current SR50 station.

3. Click the "Connect" button, and then select the "Terminal" tab.

4. On the Remote Keyboard Display Terminal click the "Open Port" button.

5. At the cursor prompt, press the "Enter" key on the keyboard until "*" is displayed.

6. At the "*" prompt, type (without the quotation marks) "7H" and press "Enter", this will give a ">" prompt.

7. At the ">" prompt press the "Shift" key and the number "8" at the same time, this will return the word "MODE".

8. At the "MODE" prompt, type the letter "A" and "MODE 10" will appear with a second line below it saying "01:0028".

9. With the cursor at the end of the "01:0028" line type "28" and press enter. This will clear the storage in Area 1.

10. The next line "02:0064" will appear, if "Enter" is pressed too many times the cursor will move to line 03 , then 04 , etc. To move back a line, press the "b" key on the keyboard. (DO NOT change any other lines other than 01; the lines should read 01:0028, 02:0064, 03:0, 04:62280, 05:+2048.0, 06:+1787.0 respectively).

11. Now at the "02:0064" prompt press the "Shift" key and the number "8" at the same time, this will return the word "MODE".

12. Check to see if Area 1 is clear, at the "MODE" prompt, type the number "7" and "MODE 071 " will appear.

13. With the cursor at the end of the "MODE 071 " line press "Enter" on the keyboard and "01+255." will appear. This indicates that the memory storage has been cleared.

14. Close terminal mode: with the cursor at the end of the "01+255." prompt, press "Enter" on the keyboard to verify $01+255$ clear signal.

15. Press the "Shift" button and the number "8" at the same time. This will return "MODE".

16 . At the end of "MODE" type " 0 ".

17. Typing "0" will return "MODE 00" on the first line, "LOG 1 " on the second line, and "*" on the third line with the cursor at the end of it.

18. Press "Enter" again, get another "*", select the "Tools" tab and click the "Disconnect" button.

\section{Onset rain gage and $\mathrm{HOBO}^{\mathrm{TM}}$ event logger instructions}

1. Inspect the station to ensure that the rain gage bucket is level and free of debris.

2. Download data.

- Connect download cable to $\mathrm{HOBO}^{\mathrm{TM}}$ Event Logger and computer serial port. 
- Open "BoxcarPro" program on the computer.

- Select the "Logger" pull down menu and select "Readout" (or press "CRTL+R"), a window will appear detailing the download status.

- Unplug the HOBO ${ }^{\mathrm{TM}}$ Event Logger from the download cable and save the file with the appropriate name.

- Review the data file (it is automatically open after you save the file) to ensure that the full range of dates is present and the data looks realistic.

- Backup the data file.

- Replace the CR2032 battery in the HOBO ${ }^{\mathrm{TM}}$ Event Logger.

Test the rain gage.

- Make sure that the $\mathrm{HOBO}^{\mathrm{TM}}$ Event Logger is connected to the tipping bucket rain gage.

- Select the "Logger" pull down menu and select "Launch", NOTE: Launching the HOBO ${ }^{\mathrm{TM}}$ Event Logger will erase all data, make sure that the logger has been downloaded and the data backed up.

- Click on the start button.

- Pour a known quality of water (the tipping bucket rain gages USGS GCMRC uses require 8.237 $\mathrm{ml}$ for one tip) slowly (the loggers are setup to record of maximum of one event per second) through the rain gage and count/record the number to tips.

- Pour water through twice.

- Download the data to check that the instrument is recording correctly, make sure that the test data is saved with a different name than the one used in the "Download data" step.

Launch the $\mathrm{HOBO}^{\mathrm{TM}}$ Event Logger.

- Select the "Logger" pull down menu and select Launch", make sure that the "Description" is the name of the station, "Event Name" is "Inches of Rain", "Event Value" is 0.01, and the "Lockout after event" box is checked and set to 00:00:01.

- Click on the start button.

- Disconnect the HOBO ${ }^{\mathrm{TM}}$ Event Logger when prompted and close BoxcarPro.

- The LED light will blink every few seconds after the logger is launched.

- Close the event logger waterproof case, taking care to ensure that the plug from the tipping bucket rain gage is secure and the desiccant pack is in place. 